\title{
Microbacterium murale sp. nov., isolated from an indoor wall
}

\author{
Correspondence \\ Peter Kämpfer \\ peter.kaempfer@umwelt.uni- \\ giessen.de
}

\author{
P. Kämpfer, ${ }^{1}$ J. Schäfer, ${ }^{1}$ N. Lodders ${ }^{1}$ and K. Martin ${ }^{2}$ \\ ${ }^{1}$ Institut für AngewandteMikrobiologie, Justus-Liebig-Universität Giessen, Ludwigstrasse 23, \\ D-35392 Giessen, Germany \\ ${ }^{2}$ Leibniz-Institut für Naturstoff-Forschung und Infektionsbiologie e. V., Hans-Knöll-Institut, \\ Beutenbergstrasse 11a, D-07745 Jena, Germany
}

The genus Microbacterium was proposed by Orla-Jensen (1919). The genus description was emended by Collins et al. (1983) and later by Takeuchi \& Hatano (1998a) to include the unification of the closely related genera Microbacterium and Aureobacterium. The genus comprises more than 70 species with validly published names (www.bacterio.cict.fr). Microbacteria are Gram-positive, non-spore-forming rods that often produce yellow colonies after growth on nutrientrich media. The members of this genus are widely distributed and can be isolated from a variety of different environmental habitats such as water (Kageyama et al., 2007, 2008), soil (Liu et al., 2005) and plants (Madhaiyan et al., 2010; Behrendt et al., 2001), but also from milk products (Orla-Jensen, 1919) and the clinical environment (Takeuchi \& Hatano, 1998b). Here we present the characterization of an isolate from the indoor environment.

Strain 01-Gi-001 ${ }^{\mathrm{T}}$ was isolated from a cellar wall in Giessen, Germany that was colonized with moulds. The isolation of bacteria from the colonized wall plaster was conducted as described by Kämpfer et al. (2009). Strain 01Gi-001 ${ }^{\mathrm{T}}$ was first maintained on organic medium M79

Abbreviation: $p N P$, para-nitrophenyl.

The GenBank/EMBL/DDBJ accession number for the $16 \mathrm{~S}$ rRNA gene sequence of strain $01-\mathrm{Gi}-001^{\top}$ is HE585693.

A supplementary figure is available with the online version of this paper.
(Medium 426; www.dsmz.de) and then on nutrient agar (Oxoid) at $30{ }^{\circ} \mathrm{C}$. Morphological properties, Gram-staining and cell morphology were tested by light microscopy as reported previously (Kämpfer \& Kroppenstedt, 2004).

The 16S rRNA gene sequence was determined as reported by Young et al. (2005). Multiple sequence alignment and analysis was performed using the ARB software package (version December 2007; Ludwig et al., 2004) and the corresponding SILVA SSURef 100 database (release August 2009; Pruesse et al., 2007). Genetic distances (pairwise distances according to the Kimura two-parameter method) were calculated and phylogenetic trees were constructed using neighbour joining (results not shown) and maximum likelihood (Fig. 1) methods. Tree building with the maximum-likelihood method was performed with fastDNAml (Olsen et al., 1994) without any filters. The 16S rRNA gene sequence of strain $01-\mathrm{Gi}-001^{\mathrm{T}}$ was a continuous stretch of $1356 \mathrm{bp}$. Using the pairwise comparison of the 16S rRNA gene sequences as implemented in the EzTaxon program (Chun et al., 2007), the sequence of strain $01-\mathrm{Gi}-001^{\mathrm{T}}$ showed $98.9 \%$ sequence similarity with Microbacterium hydrocarbonoxydans DSM $16089^{\mathrm{T}}$, $98.7 \%$ with Microbacterium profundi Shh $49^{\mathrm{T}}$, 98.3\% with Microbacterium phyllosphaerae DSM $13468^{\mathrm{T}}$, $98.1 \%$ with Microbacterium foliorum DSM $12966^{\mathrm{T}}$ and $97.9 \%$ with Microbacterium keratanolyticum IFO $13309^{\mathrm{T}}$. Similarities with all other members of the genus Microbacterium were $<97.9 \%$. 


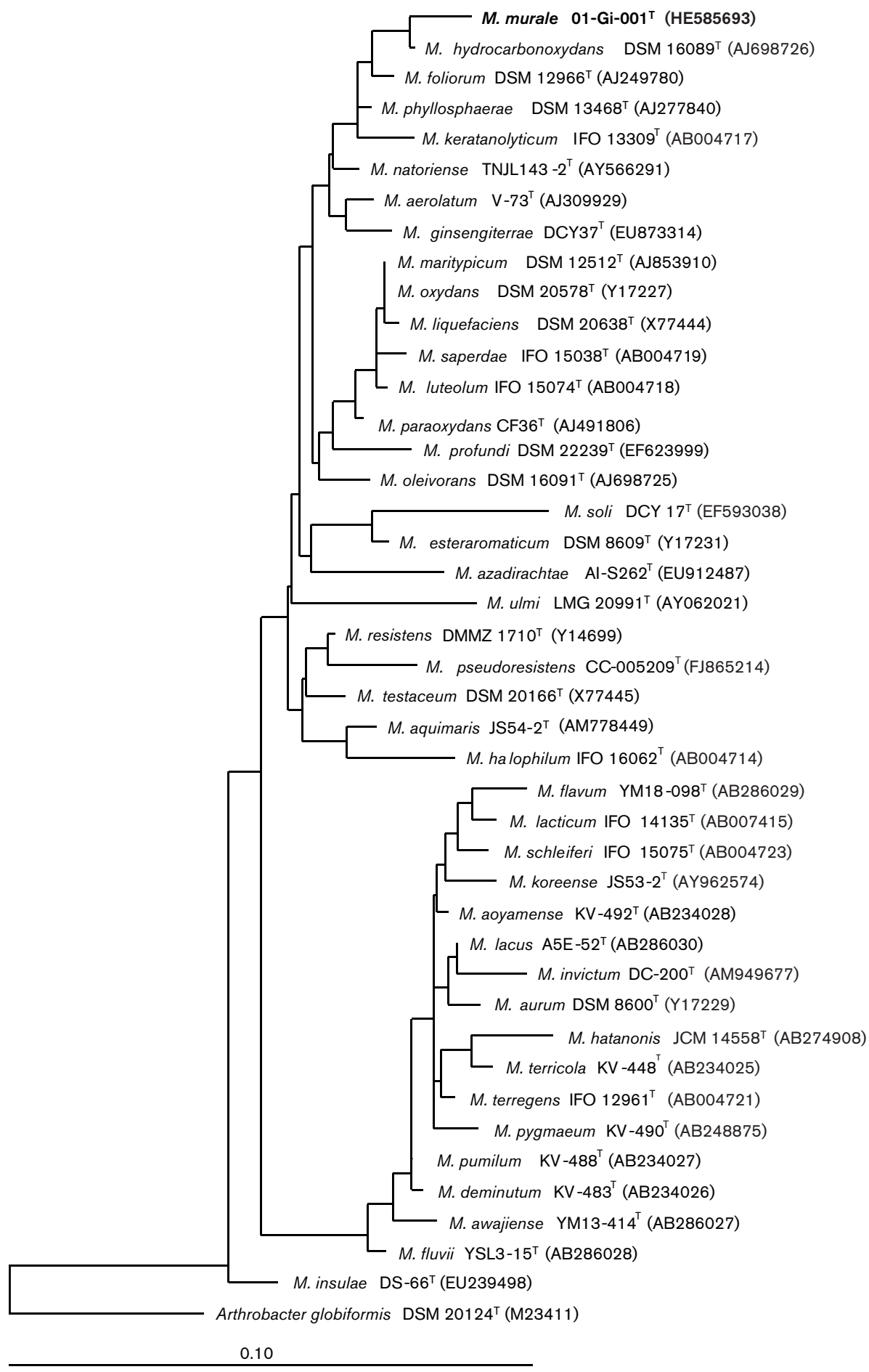

Fig. 1. Maximum-likelihood phylogenetic tree based on 16S rRNA gene sequences of type strains of selected species of the genus Microbacterium. Arthrobacter globiformis DSM $20124^{\top}$ was used as an outgroup. Bar, 0.10 substitutions per nucleotide position.

Polar lipids, diagnostic diamino acids of the peptidoglycan, whole-cell sugars and menaquinones were studied using the methods summarized by Groth et al. (1996). The polar lipids consisted of diphosphatidylglycerol, phosphatidylglycerol, one unknown glycolipid and one unknown phospholipid (Fig. S1, available in IJSEM Online). These major polar lipids have been detected in numerous members of the genus Microbacterium (Zlamala 
et al., 2002; Rivas et al., 2004; Kim et al., 2005; Buczolits et al., 2008; Park et al., 2006; Young et al., 2010) and were listed in the emended genus description (Takeuchi \& Hatano, 1998a). The peptidoglycan hydrolysates, analysed by TLC on cellulose plates using the solvent systems as described by Schleifer \& Kandler (1972), contained glycine, alanine, glutamic acid, homoserine and the diagnostic diamino acid ornithine, corresponding to peptidoglycan type B2 $\beta$ according to Schleifer \& Kandler (1972). The results of the TLC analysis were confirmed by GC-MS analysis. After derivatization of the peptidoglycan hydrolysates with $\mathrm{N}$-methyl- $\mathrm{N}$ (trimethylsilyl)trifluoroacetamide, the amino acid trimethylsilylates were analysed as described by Roessner et al. (2000). The whole-cell sugars, determined by TLC (Becker et al., 1965), were mannose and glucose. The major menaquinones of strain $01-\mathrm{Gi}-001^{\mathrm{T}}$, extracted as described by Collins et al. (1977) and analysed by HPLC (Groth et al., 1996), were MK13 and MK-12, and minor amounts of MK-11 and MK-10 were also detected (molar ratio $48: 45: 3: 2$ ). This menaquinone composition is similar to those of other members of the genus Microbacterium (e.g. Li et al., 2005; Young et al., 2010).

The fatty acid analysis was performed according to Kämpfer \& Kroppenstedt (1996). Cells of strain 01-Gi-001 ${ }^{\mathrm{T}}, M$. hydrocarbonoxydans DSM $16089^{\mathrm{T}}$, M. foliorum DSM $12966^{\mathrm{T}}$, M. phyllosphaerae DSM $13468^{\mathrm{T}}$ and M. keratanolyticum DSM $8606^{\mathrm{T}}$ were harvested after incubation at $28{ }^{\circ} \mathrm{C}$ for $48 \mathrm{~h}$ on tryptone soy agar (Oxoid). Because the colony development of all strains was very similar, it can be assumed that the strains were in comparable growth phases. The fatty acids were identified using Sherlock version 2.11 and the TSBA40 Rev. 4.1 database (MIDI). The fatty acid composition of strain $01-\mathrm{Gi}-001^{\mathrm{T}}$ was very similar to those of the reference strains (Table 1). The major fatty acids were anteiso- $\mathrm{C}_{15: 0}$, iso- $\mathrm{C}_{16: 0}$ and anteiso- $\mathrm{C}_{17: 0}$.

The results of the comparative physiological characterization for strain $01-\mathrm{Gi}-001^{\mathrm{T}}$ are given in the species description and are compared with those obtained from the reference strains under identical test conditions (Kämpfer et al., 1991) in Table 2. DNA-DNA hybridization was performed with $M$.

Table 1. Fatty acid compositions of strain $01-\mathrm{Gi}-001^{\top}$ and its closest phylogenetic neighbours in the genus Microbacterium

Strains: 1, 01-Gi-001 ${ }^{\mathrm{T}} ; 2$, M. hydrocarbonoxydans DSM $16089^{\mathrm{T}} ; 3, \mathrm{M}$. foliorum DSM $12966^{\mathrm{T}}$; 4, M. phyllosphaerae DSM $13468^{\mathrm{T}}$; 5, M. keratanolyticum DSM $8606^{\mathrm{T}}$. All data were taken from this study.

\begin{tabular}{|c|c|c|c|c|c|}
\hline Fatty acid (\%) & 1 & 2 & 3 & 4 & 5 \\
\hline iso- $\mathrm{C}_{14: 0}$ & 1.6 & 1.0 & 0.5 & 0.4 & 7.5 \\
\hline $\mathrm{C}_{14: 0}$ & 0.6 & - & - & - & - \\
\hline iso- $\mathrm{C}_{15: 0}$ & 4.9 & 4.2 & 2.8 & 6.0 & 13.5 \\
\hline anteiso- $\mathrm{C}_{15: 0}$ & 48.5 & 59.7 & 56.5 & 46.9 & 44.8 \\
\hline iso- $\mathrm{C}_{16: 0}$ & 20.1 & 14.7 & 13.7 & 18.5 & 27.5 \\
\hline$C_{16: 0}$ & 2.9 & 3.0 & 7.5 & 9.7 & 0.6 \\
\hline iso- $\mathrm{C}_{17: 0}$ & 1.0 & 0.9 & 0.8 & 3.2 & 1.6 \\
\hline anteiso- $\mathrm{C}_{17: 0}$ & 20.2 & 16.0 & 17.9 & 14.7 & 4.7 \\
\hline
\end{tabular}

Table 2. Phenotypic characteristics of strain $01-\mathrm{Gi}-001^{\top}$ and its closest phylogenetic neighbours in the genus Microbacterium

Strains: 1, 01-Gi-001 ${ }^{\mathrm{T}} ; 2$, M. hydrocarbonoxydans DSM $16089^{\mathrm{T}} ; 3, \mathrm{M}$. foliorum DSM $12966^{\mathrm{T}}$; 4, M. phyllosphaerae DSM $13468^{\mathrm{T}}$; 5, M. keratanolyticum DSM $8606^{\mathrm{T}}$. All data were taken from this study. All strains utilized $N$-acetyl-D-galactosamine, $N$-acetyl-D-glucosamine, cellobiose, D-galactose, D-glucose, D-mannose, maltose, D-ribose, sucrose and trehalose, and hydrolysed aesculin, $p \mathrm{NP}-\alpha-\mathrm{D}-$ glucopyranoside, $p$ NP- $\beta$-D-glucopyranoside, bis- $p$ NP-phosphate and $p$ NP-phenylphosphonate. None of the strains utilized D-adonitol, myo-inositol, trans-aconitate, adipate, 4-aminobutyrate, azelate, citrate, itaconate, mesaconate, suberate, L-tryptophan, DL-3-hydroxybenzoate and DL-4hydroxybenzoate. oNP, ortho-Nitrophenyl; pNA, para-nitroanilide; pNP, para-nitrophenyl; + , positive; $(+)$, weakly positive; - negative.

\begin{tabular}{|c|c|c|c|c|c|}
\hline Characteristic & 1 & 2 & 3 & 4 & 5 \\
\hline \multicolumn{6}{|l|}{ Hydrolysis of: } \\
\hline$o \mathrm{NP}-\beta$-D-galactopyranoside & + & + & + & + & - \\
\hline$p \mathrm{NP}-\beta$-D-glucuronide & + & - & - & - & - \\
\hline$p$ NP- $\beta$-D-xylopyranoside & + & - & + & + & - \\
\hline pNP-phosphoryl-choline & + & + & - & - & - \\
\hline 2-Deoxythymidine- $5^{\prime}-p N P$-phosphate & + & + & - & - & - \\
\hline L-Alanine- $p \mathrm{NA}$ & + & - & + & + & + \\
\hline L-Glutamate- $\gamma$-3-carboxy- $p$ NA & + & - & - & & - \\
\hline L-Proline-pNA & - & - & + & + & + \\
\hline \multicolumn{6}{|l|}{ Assimilation of: } \\
\hline L-Arabinose & + & + & + & + & - \\
\hline$p$-Arbutin & + & + & - & + & - \\
\hline D-Fructose & + & + & + & + & - \\
\hline Gluconate & + & - & + & + & + \\
\hline$\alpha$-Melibiose & - & - & - & + & - \\
\hline L-Rhamnose & - & + & - & + & - \\
\hline Salicin & + & + & + & + & - \\
\hline D-Xylose & + & + & + & + & - \\
\hline D-Maltitol & - & + & - & - & - \\
\hline D-Mannitol & - & + & + & - & - \\
\hline D-Sorbitol & - & + & - & - & - \\
\hline Putrescine & + & + & - & + & + \\
\hline Acetate & - & $(+)$ & - & $(+)($ & $(+)$ \\
\hline Propionate & - & $(+)$ & - & $(+)($ & $(+)$ \\
\hline cis-Aconitate & + & - & - & - & - \\
\hline Fumarate & + & $(+)$ & + & + & - \\
\hline Glutarate & + & $(+)$ & - & - & - \\
\hline DL-3-Hydroxybutyrate & + & $(+)$ & - & - & - \\
\hline DL-Lactate & + & + & - & + & - \\
\hline L-Malate & + & + & - & + & - \\
\hline Oxoglutarate & + & $(+)$ & - & - & + \\
\hline Pyruvate & + & $(+)$ & - & + & + \\
\hline L-Alanine & + & - & + & + & + \\
\hline$\beta$-Alanine & + & $(+)$ & - & - & - \\
\hline L-Aspartate & + & + & - & + & + \\
\hline L-Histidine & + & $(+)$ & - & - & - \\
\hline L-Leucine & + & $(+)$ & - & $(+)$ & - \\
\hline L-Ornithine & + & - & - & $(+)$ & - \\
\hline L-Phenylalanine & + & - & - & - & - \\
\hline L-Proline & + & + & - & + & + \\
\hline L-Serine & + & - & - & - & - \\
\hline Phenylacetate & + & - & - & + & - \\
\hline
\end{tabular}


hydrocarbonoxydans DSM $16089^{\mathrm{T}}$, M. profundi DSM $22239^{\mathrm{T}}$, M. phyllosphaerae DSM $13468^{\mathrm{T}}$, M. foliorum DSM $12966^{\mathrm{T}}$ and M. keratanolyticum DSM $8606^{\mathrm{T}}$ according to the method of Ziemke et al. (1998). Strain 01-Gi-001 ${ }^{\mathrm{T}}$ exhibited $45.7 \%$ (37.5\% reciprocal analysis) DNA-DNA relatedness with $M$. hydrocarbonoxydans DSM $16089^{\mathrm{T}}, 49.7 \%(28.4 \%)$ with $M$. profundi DSM $22239^{\mathrm{T}}, 21.5 \%(52.8 \%)$ with $M$. phyllosphaerae DSM $13468^{\mathrm{T}}, 37.6 \%(28.3 \%)$ with M. foliorum DSM $12966^{\mathrm{T}}$ and $30.6 \%(27.7 \%)$ with M. keratanolyticum DSM $8606^{\mathrm{T}}$.

The quinone system, peptidoglycan type, fatty acid composition and polar lipid profile, as well as the $16 \mathrm{~S}$ rRNA gene sequence analysis, showed clearly that strain $01-\mathrm{Gi}-001^{\mathrm{T}}$ belongs to the genus Microbacterium. On the basis of the observed phenotypic differences, DNA-DNA relatedness and differences in 16S rRNA gene sequences, we propose that the isolate represents a novel species, Microbacterium murale sp. nov.

\section{Description of Microbacterium murale sp. nov.}

Microbacterium murale (mu.ra'le. L. neut. adj. murale of or belonging to a wall).

Cells are Gram-positive, short rods, about 2-3 $\mu \mathrm{m}$ long and 1$1.2 \mu \mathrm{m}$ wide. Oxidase- and catalase-positive, showing an aerobic respiratory metabolism. Good growth occurs after 3 days on nutrient agar, R2A agar and tryptone soy agar at 25$30{ }^{\circ} \mathrm{C}$, and yellow colonies are produced on these media. The amino acids of the peptidoglycan are glycine, alanine, glutamic acid, homoserine and the diagnostic diamino acid ornithine. The whole-cell sugars are mannose and glucose. The quinone system is composed of major amounts of MK-13 and MK-12, and minor amounts of MK-11 and MK-10. The polar lipid profile consists of phosphatidylglycerol, diphosphatidylglycerol, one unknown phospholipid and one unknown glycolipid. Major fatty acids are anteiso- $\mathrm{C}_{15: 0}$, iso- $\mathrm{C}_{16: 0}$ and anteiso- $\mathrm{C}_{17: 0}$. Utilizes $\mathrm{N}$-acetyl-D-glucosamine, $\mathrm{N}$-acetyl-Dgalactosamine, cellobiose, gluconate, D-glucose, D-ribose, Dmannose, D-xylose, L-arabinose, p-arbutin, D-galactose, D-fructose, sucrose, maltose, trehalose, putrescine, fumarate, glutarate, cis-aconitate, DL-3-hydroxybutyrate, DL-lactate, Lmalate, pyruvate, oxoglutarate, L-alanine, $\beta$-alanine, L-aspartate, L-leucine, phenylacetate, phenylalanine and L-histidine as sole carbon sources, but not D-adonitol, $\alpha$-melibiose, Lrhamnose, D-mannitol, D-maltitol, inositol, sorbitol, acetate, propionate, adipate, azelate, suberate, mesaconate, citrate, Ltryptophan, DL-3-hydroxybenzoate or DL-4-hydroxybenzoate. Hydrolyses aesculin, $p \mathrm{NP}-\alpha$-D-glucopyranoside, $p \mathrm{NP}-\beta$-D-glucopyranoside, bis- $p$ NP-phosphate and $p$ NP-phenyl-phosphonate. Other physiological characteristics are given in Table 2.

The type strain is $01-\mathrm{Gi}-001^{\mathrm{T}}\left(=\mathrm{DSM} \quad 22178^{\mathrm{T}}=\mathrm{CCM}\right.$ $7640^{\mathrm{T}}$ ), which was isolated from an indoor wall colonized with moulds in Giessen, Germany.

\section{Acknowledgements}

We are grateful to Carmen Schult, Christiane Weigel, Gundula Will and Maria Sowinsky for excellent technical assistance, and Dr H.-P.
Klenk and Dr E. Falsen for providing type strains of species of the genus Microbacterium for comparison.

\section{References}

Becker, B., Lechevalier, M. P. \& Lechevalier, H. A. (1965). Chemical composition of cell-wall preparations from strains of various formgenera of aerobic actinomycetes. Appl Microbiol 13, 236-243.

Behrendt, U., Ulrich, A. \& Schumann, P. (2001). Description of Microbacterium foliorum sp. nov. and Microbacterium phyllosphaerae sp. nov., isolated from the phyllosphere of grasses and the surface litter after mulching the sward, and reclassification of Aureobacterium resistens (Funke et al. 1998) as Microbacterium resistens comb. nov. Int J Syst Evol Microbiol 51, 1267-1276.

Buczolits, S., Schumann, P., Valens, M., Rosselló-Mora, R. \& Busse, H.-J. (2008). Identification of a bacterial strain isolated from the liver of a laboratory mouse as Microbacterium paraoxydans and emended description of the species Microbacterium paraoxydans Laffineur et al 2003. Int J Microbiol 48, 243-251.

Chun, J., Lee, J.-H., Jung, Y., Kim, M., Kim, S., Kim, B. K. \& Lim, Y.-W. (2007). EzTaxon: a web-based tool for the identification of prokaryotes based on $16 \mathrm{~S}$ ribosomal RNA gene sequences. Int J Syst Evol Microbiol 57, 2259-2261.

Collins, M. D., Pirouz, T., Goodfellow, M. \& Minnikin, D. E. (1977). Distribution of menaquinones in actinomycetes and corynebacteria. J Gen Microbiol 100, 221-230.

Collins, M. D., Jones, D. \& Kroppenstedt, R. M. (1983). Reclassification of Brevibacterium imperiale (Steinhaus) and 'Corynebacterium laevaniformans' (Dias and Bhat) in a redefined genus Microbacterium (Orla-Jensen) as Microbacterium imperiale comb. nov. and Microbacterium laevaniformans nom. rev.; comb. nov. Syst Appl Microbiol 4, 65-78.

Groth, I., Schumann, P., Weiss, N., Martin, K. \& Rainey, F. A. (1996). Agrococcus jenensis gen. nov., sp. nov., a new genus of actinomycetes with diaminobutyric acid in the cell wall. Int J Syst Bacteriol 46, 234239.

Kageyama, A., Takahashi, Y., Matsuo, Y., Adachi, K., Kasai, H., Shizuri, Y. \& Ōmura, S. (2007). Microbacterium flavum sp. nov. and Microbacterium lacus sp. nov., isolated from marine environments. Actinomycetologica 21, 53-58.

Kageyama, A., Matsuo, Y., Kasai, H., Shizuri, Y., Ōmura, S. \& Takahashi, Y. (2008). Microbacterium awajiense sp. nov., Microbacterium fluvii sp. nov. and Microbacterium pygmaeum sp. nov. Actinomycetologica 22, 1-5.

Kämpfer, P. \& Kroppenstedt, R. M. (1996). Numerical analysis of fatty acid patterns of coryneform bacteria and related taxa. Can $J$ Microbiol 42, 989-1005.

Kämpfer, P. \& Kroppenstedt, R. M. (2004). Pseudonocardia benzenivorans sp. nov. Int J Syst Evol Microbiol 54, 749-751.

Kämpfer, P., Steiof, M. \& Dott, W. (1991). Microbiological characterisation of a fuel-oil contaminated site including numerical identification of heterotrophic water and soil bacteria. Microb Ecol 21, 227-251.

Kämpfer, P., Martin, K., Schäfer, J. \& Schumann, P. (2009). Kytococcus aerolatus sp. nov., isolated from indoor air in a room colonized with moulds. Syst Appl Microbiol 32, 301-305.

Kim, K. K., Park, H. Y., Park, W., Kim, I. S. \& Lee, S.-T. (2005). Microbacterium xylanilyticum sp. nov., a xylan-degrading bacterium isolated from a biofilm. Int J Syst Evol Microbiol 55, 2075-2079.

Li, W.-J., Chen, H.-H., Kim, C.-J., Park, D.-J., Tang, S.-K., Lee, J.-C., Xu, L.-H. \& Jiang, C.-L. (2005). Microbacterium halotolerans sp. nov., 
isolated from a saline soil in the west of China. Int J Syst Evol Microbiol 55, 67-70.

Liu, J., Nakayama, T., Hemmi, H., Asano, Y., Tsuruoka, N., Shimomura, K., Nishijima, M. \& Nishino, T. (2005). Microbacterium natoriense sp. nov., a novel D-aminoacylase-producing bacterium isolated from soil in Natori, Japan. Int J Syst Evol Microbiol 55, 661665.

Ludwig, W., Strunk, O., Westram, R., Richter, L., Meier, H., Yadhukumar, Buchner, A., Lai, T., Steppi, S. \& other authors (2004). ARB: a software environment for sequence data. Nucleic Acids Res 32, 1363-1371.

Madhaiyan, M., Poonguzhali, S., Lee, J. S., Lee, K. C., Saravanan, V. S. \& Santhanakrishnan, P. (2010). Microbacterium azadirachtae sp. nov., a plant-growth-promoting actinobacterium isolated from the rhizoplane of neem seedlings. Int J Syst Evol Microbiol 60, 1687-1692.

Olsen, G. J., Matsuda, H., Hagstrom, R. \& Overbeek, R. (1994). fastDNAmL: a tool for construction of phylogenetic trees of DNA sequences using maximum likelihood. Comput Appl Biosci 10, 41-48.

Orla-Jensen, S. (1919). The Lactic Acid Bacteria. Copenhagen: Host \& Sons.

Park, H. Y., Kim, K. K., Jin, L. \& Lee, S.-T. (2006). Microbacterium paludicola sp. nov., a novel xylanolytic bacterium isolated from swamp forest. Int J Syst Evol Microbiol 56, 535-539.

Pruesse, E., Quast, C., Knittel, K., Fuchs, B. M., Ludwig, W., Peplies, J. \& Glöckner, F. O. (2007). SILVA: a comprehensive online resource for quality checked and aligned ribosomal RNA sequence data compatible with ARB. Nucleic Acids Res 35, 7188-7196.

Rivas, R., Trujillo, M. E., Sánchez, M., Mateos, P. F., Martínez-Molina, E. \& Velázquez, E. (2004). Microbacterium ulmi sp. nov., a xylanolytic, phosphate-solubilizing bacterium isolated from sawdust of Ulmus nigra. Int J Syst Evol Microbiol 54, 513-517.

Roessner, U., Wagner, C., Kopka, J., Trethewey, R. N. \& Willmitzer, L. (2000). Simultaneous analysis of metabolites in potato tuber by gas chromatography-mass spectrometry. Plant J 23, 131-142.

Schleifer, K. H. \& Kandler, O. (1972). Peptidoglycan types of bacterial cell walls and their taxonomic implications. Bacteriol Rev 36, 407-477.

Takeuchi, M. \& Hatano, K. (1998a). Union of the genera Microbacterium Orla-Jensen and Aureobacterium Collins et al. in a redefined genus Microbacterium. Int J Syst Bacteriol 48, 739-747.

Takeuchi, M. \& Hatano, K. (1998b). Proposal of six new species in the genus Microbacterium and transfer of Flavobacterium marinotypicum ZoBell and Upham to the genus Microbacterium as Microbacterium maritypicum comb. nov. Int J Syst Bacteriol 48, 973-982.

Young, C.-C., Kämpfer, P., Shen, F.-T., Lai, W.-A. \& Arun, A. B. (2005). Chryseobacterium formosense sp. nov., isolated from the rhizosphere of Lactucasativa L. (garden lettuce). Int J Syst Evol Microbiol 55, 423-426.

Young, C.-C., Busse, H.-J., Langer, S., Chu, J.-N., Schumann, P., Arun, A. B., Shen, F.-T., Rekha, P. D. \& Kämpfer, P. (2010). Microbacterium agarici sp. nov., Microbacterium humi sp. nov. and Microbacterium pseudoresistens sp. nov., isolated from the base of the mushroom Agaricus blazei. Int J Syst Evol Microbiol 60, 854-860.

Ziemke, F., Höfle, M. G., Lalucat, J. \& Rosselló-Mora, R. (1998). Reclassification of Shewanella putrefaciens Owen's genomic group II as Shewanella baltica sp. nov. Int J Syst Bacteriol 48, 179-186.

Zlamala, C., Schumann, P., Kämpfer, P., Valens, M., Rosselló-Mora, R., Lubitz, W. \& Busse, H.-J. (2002). Microbacterium aerolatum sp. nov., isolated from the air in the 'Virgilkapelle' in Vienna. Int J Syst Bacteriol 52, 1229-1234. 